\title{
Sovereign, Saint, and City: Honor and Reuse of Textiles in the Treasury of San Isidoro (León)
}

\author{
María Judith Feliciano
}

\begin{abstract}
The textiles currently housed in the treasury of the collegiate church of San Isidoro de León are part of a centuries-long process of collecting relics at the heart of an emblematic royal mausoleum. Instead of studying them through the prism of the "charter of 1063," this investigation proposes a wider look at the place of luxurious textiles in Castile and León before and after the arrival of Saint Isidore's relics. What emerges is an intricate relationship between the mythification of the city of León as a civitas regia, the Leonese monarchy's concept of antiquity in legitimizing their rule, and the refinement associated with the royal court and its sacred performance of the cults of saints.
\end{abstract}

\section{Keywords}

saints' relics - textile reuse - Arabic epigraphy - țirāz - reliquary linings

A study of the textile collection associated with the treasury of the Collegiate Church of San Isidoro de León presents extraordinary challenges to historians. ${ }^{1}$

1 The following grants and institutions provided crucial support for the work that culminated in this article: invaluable direct access to the textiles was made possible by The Medieval Treasury across Frontiers and Generations: The Kingdom of León-Castilla in the Context of Muslim-Christian Interchange, c. 1050-1200 (PI, Therese Martin, Spanish Ministry of Economy and Competitivity, HAR2015-68614-P); the Max Van Berchem Foundation funded the epigraphic work through its support of the Medieval Textiles in Iberia and the Mediterranean Research Project; Las manufacturas textiles andalusíes: caracterización y estudio interdisciplinar (PI, Laura Rodríguez Peinado, Spanish Ministry of Economy and Competitivity, HAR2o1454918-P) underwrote the scientific analyses of the textiles; and the Princeton Institute for International and Regional Studies at Princeton University provided an ideal forum for crossdisciplinary dialogue in The Medieval Iberian Treasury in the Context of Muslim-Christian Interchange conference. I would also like to express my heartfelt gratitude to Therese Martin for her diligent and thoughtful editorial support. 
From the common notion of the present-day treasury as the exclusive repository of a single royal donation by Fernando I and Sancha of León in 1063 to the deceptive and largely undocumented impact of nineteenth- and earlytwentieth century interventions and collecting practices, the history of the treasury has been anchored by incomplete evidence and unverified oral histories. ${ }^{2}$ Its collection - which at fourteen extant textiles is uniquely diverse if relatively small — has not been the focus of scientific or comprehensive historical analyses until now. Instead, formal descriptions have tied the textiles to an Andalusi periodization that is difficult to substantiate. Yet, a methodical review of historical documentation, together with scientific analyses of the fibers and structural examination of the cloths, reveals a new chronology of materials that both precede and post-date the 1063 donation to San Isidoro. ${ }^{3}$ A commercial map that links the Kingdom of León with woven goods fashioned far beyond the frontiers of al-Andalus and the Mediterranean, expanding into Central Asia, also unfolds. Ultimately, the present-day assembly of textile objects at the Museo de la Real Colegiata de San Isidoro emerges not as the treasury of Fernando and Sancha, but rather as a far more elaborate collection of medieval objects that was essential in the construction of majesty and sanctity in a city founded as a civitas regia. ${ }^{4}$ The textiles at San Isidoro were part of an evolving compendium of sacred objects at the service of the Church, the monarchy, and the city of León. ${ }^{5}$

Indeed, recognizing the relationship between the enduring royal, sacred, and historic sources of local identity is essential to an understanding of the wide range of dates - from the ninth through the thirteenth centuriesrepresented by the treasury's extant textiles. As Monsalvo Antón has argued, it was not too long after 910-914, when the court of the Astur-Leonese

2 On the debate surrounding the 1063 donation, see María Encarnación Martín López, Patrimonio cultural de San Isidoro de León: Documentos de los siglos X-XIII. (León: Universidad de León, 1995), 38-39. See also Chpt. 2 by Therese Martin in this volume.

3 For a detailed analysis of the technical approaches to dating and characterizing the textiles at San Isidoro, see Chpt. 4 by Ana Cabrera in this volume.

4 On León as a royal city, see Peter Linehan, "León, ciudad regia, y sus obispos en los siglos X-XIII," in El Reino de León en la Alta Edad Media, 12 vols. (León: Centro de Estudios e Investigaciones "San Isidoro" (CSIC-CECEL), Caja de Ahorros y Monte de Piedad, Archivo Histórico Diocesano, 1994), 6: 409-457. See also Carlos Reglero de la Fuente, "Restauración diocesana y memoria regia en León y Castilla," in La construcción medieval de la memoria regia, ed. Pascual Martínez Sopena and Ana Rodríguez (Valencia: Universidad de Valencia, 2011), 87-106.

5 This expansive reading of the textile evidence well into the early modern period echoes Therese Martin's conclusions, based on the new radiocarbon dating of the Beatitudes Casket, in Chpt. 2 of this volume. 
kingdom was transferred from Oviedo to León, that a deliberate process of mythification - of cultural and doctrinal construction - of the city began to take place. ${ }^{6}$ Central to the ideological creation of the royal capital was the physical presence of the reigning monarchs, as well as high-ranking nobility and clergy, at symbolically charged moments that reaffirmed the centrality of the city in the life of the kingdom, such as coronations and royal funerary ceremonies, victorious returns after battles, and the public humiliation of adversaries, among others. ${ }^{7}$ Of course, these displays required an illustrious backdrop, an urban environment complete with palaces, churches, monasteries, and an imposing cathedral that dignified royal pageantry. ${ }^{8}$ The ultimate reiteration of royal power in a ritualized medieval capital where the bodies of kings were anointed, exalted, and eventually entombed, was the presence of the bodies of the saints in the form of powerful relics. ${ }^{9}$ Welcome ceremonies for the arrival of relics invigorated all aspects of urban, royal, and religious display mentioned above: the city became the theater, its most important buildings and temples the stages, and large assemblies of powerful civil and ecclesiastical elites and enthralled inhabitants joined in as actors and spectators. The yearly celebration in commemoration of the martyrdom or arrival of the relics cyclically reactivated the original performance and reaffirmed its historical legacy. ${ }^{10}$

Prior to 1063, when the welcome ceremony and royal endowment for the arrival of the remains of Saint Isidore took place in León, the city's churches

$6 \quad$ He refers to this myth as "la capitalidad de León." José María Monsalvo Antón, "La imagen de las ciudades y regiones altomedievales de León y de Castilla en las crónicas generales (de Sampiro a la Estoria de España)," Studia Historica. Historia medieval 28 (2010): 83-123, esp. 86.

7 Monsalvo Antón, "La imagen de las ciudades," 87-93. An example of this process of mythification is the symbolic weight placed by contemporary and later chroniclers on the continuation of the Visigothic coronation ritual in the cathedral of León, whereby the head of the just-crowned king underwent a ceremonial anointment. See Antonio Viñayo González, Fernando I, el Magno 1035-1065 (Burgos: Editorial La Olmeda, 1999), 59-62.

8 Monsalvo Antón, "La imagen de las ciudades," 93. For a concise history of the use of relics in royal circles up to the reign of Fernando I and Sancha, see Raquel Alonso Álvarez, "La Cámara Santa de Oviedo. De thesaurus a relicario," in La Cámara Santa de Oviedo y su relicario, ed. Raquel Alonso Álvarez (Oviedo: Real Instituto de Estudios Asturianos, 2017), 59-82, esp. 65-66.

9 Monsalvo Antón, "La imagen de las ciudades," 95.

10 Peter Brown suggests "a double preoccupation with concord [between regions and within communities (my aside)] and the exercise of power" in the welcome ceremonies for saints' relics and the yearly reenactments of their arrival. Peter Brown, The Cult of the Saints: Its Rise and Function in Latin Christianity, 2nd ed. (Chicago: University of Chicago Press, 2015; first ed. 1980), 97-98. 
had already been in possession of a renowned collection of relics of local and foreign saints. Among the most venerated were the mandible of John the Baptist, the remains of Pelayo (a Leonese child martyred in Córdoba (in 925), as well as relics of saints Claudio, Vicente Abad, Froylán, Facundo, and Primitivo, among others. ${ }^{11}$ The impending siege and ultimate destruction of the city of León by the troops of the Cordoban vizier al-Mansur in the 99os prompted the safekeeping of the relics. ${ }^{12}$ Some, like those of Saints Pelayo and Vicente Abad, a sixth-century martyr, were taken north to Oviedo to escape desecration. Others were hidden or buried, while still others survived untouched. ${ }^{13}$ In 1053, sixteen years after becoming monarchs of the kingdom of León, Fernando and Sancha traveled to Asturias with a coterie of court members and prelates to ceremonially and triumphantly retrieve some of the relics of Saint Pelayo and return them to their home in León. ${ }^{14}$ The remains of saints like Pelayo, which reemerged untouched from the caliphal raids, carried the weight of victorious Christianity as their symbolic store. The translation of the relics of Saint Isidore from Muslim-controlled Sevilla in 1063 undoubtedly carried a similar association of success in returning exalted Christian remains to Christian lands, as was the case a year later when the rulers brought the body of Saint Vicente de Ávila to León "because the city of Ávila had seen great destruction by the Muslims." 15

The saintly remains mentioned above shared two common attributes: while some of the relics were laden with anti-Islamic sentiment, others were steeped in early Christian antiquity. The ways in which the Astur-Leonese kingdom conceived of its relationship to an Iberian concept of Christian antiquityand therefore legitimacy - in their contested soil are fundamental to our understanding of the textiles that wrapped the saintly remains. For instance, the remains of the child martyr Pelayo, killed in defense of his faith and virtue (he

11 For an exhaustive and detailed list of saints in the see of León, see Manuel Risco, España Sagrada (Madrid: Imprenta de Pedro Marín, 1784), 34:312-389.

12 Al-Mansur's historic raids on the region of León had begun around the year 982. For a detailed account of al-Mansur's military engagements in the north, see Ana Echevarría Arsuaga, Almanzor, un califa en la sombra (Madrid: Sílex, 2011), 119-178.

13 Risco, España Sagrada, 34:312-389.

14 For details of the event, see Francisco Javier Fernández Conde, Isabel Torrente Fernández, and Guadalupe de la Noval, El Monasterio de San Pelayo de Oviedo: Historia y fuentes, 3 vols. (Oviedo: Monasterio de San Pelayo, 1978), I:23-25.

15 For a detailed account of the search for, invention, and return of the relics of Saint Isidore, see Viñayo, Fernando I, 173-207; citing Lucas de Tuy on San Vicente de Ávila, 208. For Vicente, see also Daniel Rico Camps, "San Vicente de Ávila en el siglo XII: La restauración de un locus sanctus," Hortus Artium Medievalium 15/2 (2009): 291-305. 
is said to have resisted the religious and sexual advances of 'Abd al-Rahman III, who had become infatuated with his beauty, incurring the caliph's wrath ${ }^{16}$ likely echoed the widely circulating stories commemorating the mid-ninth century Martyrs of Córdoba championed by Eulogius and Albarus. The martyrs had upheld an uncompromising attitude towards assimilation and integration into Islamic society, viewing it as a fatal step towards corruption and the ultimate destruction of Iberian Christianity. ${ }^{17}$ The cult of their relics quickly spread to the Christian north, where trade in their remains fueled diplomatic exchanges well into the tenth century. ${ }^{18}$ Possessing and venerating the remains of Isidore of Sevilla, perhaps the best known Iberian saint and a recognized Father of the Church, connected the Leonese monarchy and faithful to an already mythologized Visigothic history. The symbolic charge of the royal custody of such celebrated remains also reaffirmed the promise of Christian reunification of the Iberian Peninsula, a theme alive in the courtly circles of the Astur-Leonese monarchy since the late ninth century. ${ }^{19}$ As Manuel Castiñeiras suggests, the traslatio of Isidore's remains to León transformed the confessor into a physical symbol of Visigothic greatness at the heart of the city. ${ }^{20}$ Similarly, saving from Muslim desecration the remains of Saint Vicente de Ávila, a Roman martyr of the Iberian church, tied these associations deeper into the history of

16 Jeffrey A. Bowman, "Beauty and Passion in Tenth-century Córdoba," in The Boswell Thesis: Essays on Christianity, Social Tolerance, and Homosexuality, ed. Mathew Kuefler (Chicago: University of Chicago Press, 2006), 236-253.

17 Jamie Wood, "Persecution, Past and Present: Memorialising Martyrdom in Late Antique and Early Medieval Córdoba," Al-Masāq. Journal of the Medieval Mediterranean 27/1 (2015): 41-6o, esp. 59 .

18 Wood, "Persecution, Past and Present," 58 , argues that Eulogius was "acutely aware of the potential of Cordoban relics to generate connections with outsiders." Mariam RosserOwen argues persuasively for the importance of Iberian relic translations within and outside of Islamic territory in the dissemination of Andalusi luxury objects. Mariam Rosser-Owen, "Islamic Objects in Christian Contexts: Relic Translation and Modes of Transfer in Medieval Iberia," Art in Translation 7/1 (2015): 39-64, esp. 50-52. See also Roger Collins, Caliphs and Kings: Spain 796-1037 (Chichester, UK and Malden, MA: WileyBlackwell, 2012), 108. On the Martyrs of Córdoba, see Kenneth Baxter Wolf, Christian Martyrs in Muslim Spain (Cambridge: Cambridge University Press, 1988); Jessica A. Coope, The Martyrs of Cordoba: Community and Family Conflict in an Age of Mass Conversion (Lincoln: University of Nebraska Press, 1995).

19 Jerrilynn D. Dodds, Architecture and Ideology in Early Medieval Spain (University Park, PA: The Pennsylvania State University Press, 1990), 77-81.

20 A similar phenomenon took place upon the return of Saint Pelayo's remains to León. Manuel A. Castiñeiras González, "El labora: los trabajos y los días en la iconografía románica," in Vida y muerte en el monasterio románico, ed. José Ángel García de Cortázar (Aguilar de Campoo: Fundación Santa María la Real, 2004), 63-84, esp. 79-8o. 
Christianity in Iberia. ${ }^{21}$ By 1053, the concepts of antiquity, both real and imaginary, were fundamental to the construction and veneration of the assembled relics as a sort of heavenly court in León.

The extant textiles in the treasury of San Isidoro speak directly of this sense of antiquity and legitimacy channeled through relics. The early dating revealed by carbon-14 tests for the two textiles lining the reliquary of San Isidoro80o-96o for the weaving, 878-1013 for the embroidery ${ }^{22}$ - may seem surprising to us today because these silks are almost always associated with the royal gift of 1063 (Figures 5.1 and 5.2). Shortly after the miraculous appearance in a dream of Saint Isidore to Bishop Alvito in Sevilla, we are told that Isidore's relics traveled to their resting place in León in a spectacular fashion. ${ }^{23}$ The Historia Silense tells us that al-Mu'tadid of Sevilla (r. 1042-1069) shrouded the reliquary in a magnificent textile ("ecce Rex Sarracenorum supradictus Abenhabet cortinam miro opera contextam super sacrcophagum Beati Confessoris iactavit ..."). ${ }^{24}$ In the post-industrial age, we are conditioned to think that the textiles used for such a symbolically freighted purpose as a saint's journey and ceremonial entry into a city would have been newly purchased because culturally we are expected neither to gift old things nor to wear old clothes at important public acts. It is an incontrovertible fact, however, that the reuse of fine textiles, especially those that had undergone ritual consecration for the ornament of sacred spaces or to facilitate liturgical ritual, was the medieval norm. ${ }^{25} \mathrm{In}$

21 Beyond patterning "the Cordoban martyrs on earlier (Roman) saints," Wood argues for Eulogius' further manipulation of the relics of the Martyrs of Córdoba by tying them directly to sites of Roman martyria in al-Andalus (Wood, "Persecution," 51-55).

22 For technical dating details, see Ana Cabrera's contribution to this volume.

23 For the translation, see José Carlos Martín, "La Translatio S. Isidori Legionem Anno 1063 (BHL 4488): Introducción, estudio y edición crítica," Exemplaria Classica. Journal of Classical Philology 15 (2011): 225-253.

24 Henrique Flórez, España Sagrada. Theatro geographico-histórico de la Iglesia de España (Madrid: Oficina de Pedro Marín, 1789), 17:319. Spanish edition: Introducción a la Historia Silense, ed. Manuel Gómez-Moreno (Madrid: Centro de Estudios Históricos, 1921), 131: "Echó una cortina, tejida con admirable labor sobre el sarcófago del confesor bienaventurado."

25 In medieval Islamic societies, rituals of investiture highlighted the imposition of the honorific khil'a - which is essentially what al-Mu'taḍid did upon ritually clothing Saint Isidore's casket before its departure from his realm. As Sanders explained, "at its most literal, a khil'a (pl. khila) is a garment that has been taken off (khala'a) by one person and given to another ... While earlier rulers certainly bestowed such 'castoff' garments as honorific robes, the term khil'a came into usage in the 'Abbasid period (750-1258). In time, it was used to designate any garment bestowed by the ruler upon an official ... [in Fatimid Egypt] castoff $k h i l a^{c}$ were especially prized as funeral shrouds, and they might be given in response to a specific request." It is unclear, however, what the protocol was in the 


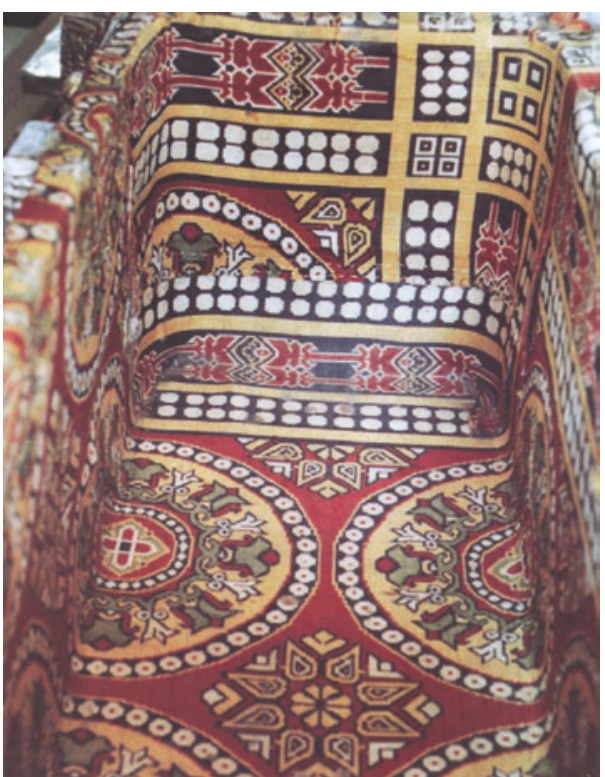

FIGURE 5.1

Textile lining the reliquary of San Isidoro (Museo de la Real Colegiata de San Isidoro de León, Inv. No. IIC-3-089-002-0oo1). PHOTO: ANA CABRERA

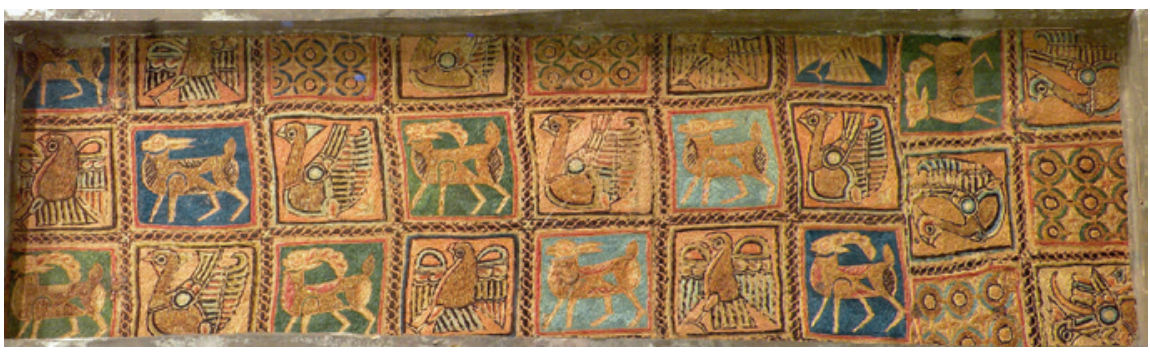

FIGURE 5.2 Embroidery lining the lid of the reliquary of San Isidoro (Museo de la Real Colegiata de San Isidoro de León, Inv. No. IIC-3-089-0o2-0oo1). See also Figs. 4.4, 4.7. PHOTO: THERESE MARTIN

fact, we can trace the presence of luxury textiles in the Christian kingdoms of the Iberian Peninsula from at least the ninth century.

The history of early acquisitions of luxury textiles in the northern Iberian kingdoms is rich, indeed. Ninth-century documents mention textile gifts by

eleventh-century Taifa court of Sevilla. On the khil'a, see Paula Sanders, "Robes of Honor in Fatimid Egypt," in Robes and Honor. The Medieval World of Investiture, ed. Stewart Gordon (New York: Palgrave, 2001), 225-239, esp. 226-227. See also N. E. Stillman, "Khil'a" in The Encyclopedia of Islam, 12 Volumes. 2nd ed., ed. H. A. R. Gribb et al. (Leiden: Brill, 1960), 5:6-7. 
Bishop Frunimio I to Santa Eulalia de Vinagio (Valle del Duero, 873) and from King Alfonso III to San Adriano de Tuñón (Asturias, 891). ${ }^{26}$ At the monastery of Abeliare (Asturias), the 927 testament of its founder, Bishop Cixila, itemized more than seventy fine textiles in his personal possession. ${ }^{27}$ In the neighboring county, the documentation tells us, for instance, that in 978 the ruling count and countess of Castile, García and Ava, founded the monastery of Covarrubias for their daughter Urraca, donating to the new institution a series of textiles including Byzantine silks (greciscos). ${ }^{28}$ This charter is particularly noteworthy because it details the role of textile gifts to ornament and dignify the cult in a newly established temple; such foundational objects would themselves eventually become a type of relic.

Currently housed in the Museo de la Colegiata de Covarrubias, a tirāz-like white linen textile with borders of colorful tapestry weave depicting waterfowl was retrieved from a lipsanotheca in the nearby monastery of San Pedro de Arlanza. ${ }^{29}$ Lipsanothecas were small wooden boxes containing relics and/or

26 In León, an early surviving document dated 874 details a donation of tapestry-weave (palleos) altar frontals, curtains or long lengths of textiles with birds and eagles, and "greciscos" or Byzantine silks, given by Bishop Frunimio I to the Cathedral of León. Sánchez-Albornoz consulted and recorded the document, but it does not appear among the Cathedral documents subsequently published for this period. Document 1326 of the Archivo de la Catedral de León, cited by Claudio Sánchez-Albornoz, Una ciudad de la España cristiana hace mil años (Madrid: Ediciones Rialp, 2014; first ed. 1924), 136, n. 68. Cited from Manuel Risco, España Sagrada (Madrid: Oficina de Blas Román, 1784), xxxıv: 427; and Manuel Risco, España Sagrada (Madrid: Oficina de Blas Román, 1789), XXXVII: 339.

27 It includes sheets, table (altar?) covers, handkerchiefs, tunics, albs, tapestries, and many other objects. As cited from the Becerro I de la Catedral de León, f. 385 by Manuel GómezMoreno, Iglesias mozárabes. Arte español de los siglos IX-XI. Edición facsímil. Estudio preliminar por Isidro Bango Torviso (Granada: Universidad de Granada, 1998; first ed. 1919), 326-327.

28 From the Cartulario de Covarrubias, as cited by Sánchez-Albornoz, Una ciudad, 43. "Et donavit tibi XX. lectos cum suos tapetes et almocallas de palleo et de greciscos et suos plumacos palleos et greciscos et suas savanas litteratas et fateles alfaneges in pannos greciscos ..." Cartulario del Infantado de Covarrubias, ed. Luciano Serrano (Madrid: Gregorio del Amo, 1907), II:22. See also thirteen documentary references to greciscos, especially in relation to ecclesiastical vestments (chasubles, dalmatics, stoles, etc.) and ritual objects (table covers, altar frontals, etc.) in Sánchez-Albornoz, Una ciudad, 42, n. 5 .

29 Technically, the term țirāz refers to an "inscription band in Islamic textiles, or fabric with an inscription band added in a technique different from the ground weave ... tirīäz also refers to the workshop in which these textiles were made." The category also includes woven textiles with a tapestry band decoration in linen, silk, or mulham (a cotton-silk combination) even without inscription. See The Grove Encyclopedia of Islamic Art and Architecture, ed. Jonathan A. Bloom and Sheila S. Blair, 3 vols. (Oxford: Oxford University Press, 2009), I:337-340. Carmen Bernis, "Tapicería hispano-musulmana (siglos XIIIXIV)," Archivo Español de Arte 29 (1956): 189-211, esp. 98, 202; Florence May, Silk Textiles of 
small folded texts detailing important events in the history of an early medieval institution, such as the consecration of a new church or the expansion of a pre-existing temple. ${ }^{30}$ Common from the tenth to the thirteenth centuries in the Iberian Peninsula, lipsanothecas could be placed in a hole in a wall or the floor of the apse, in an altar, or within a larger reliquary. A single church could have multiple such commemorative objects throughout its history. The famous tirāz from Colls (Museo de Huesca), found in 1978 in the Aragonese Pyrenees and generally thought to be a caliphal work, was discovered wrapping a lipsanotheca ("una caja de reliquias") within the altar of a ruined twelfth-century church (Figure 5.3). ${ }^{31}$ As for the aforementioned textile from San Pedro de Arlanza, this very early piece, likely of Egyptian Fatimid manufacture, must already have been seen as a relic of the monastery's past at the time of its insertion into the lipsanotheca. ${ }^{32}$ It bears mentioning that Covarrubias and Arlanza constitute the spiritual and symbolic seats of the county of Castile. Covarrubias is the mausoleum of the counts of Castile, while San Pedro de Arlanza, known as the "cradle of Castile," is associated with a foundation, or perhaps reedification, in 912 by Count Fernán González. ${ }^{33}$ Together with Oña, Arlanza

Spain. Eighth to Fifteenth Century (New York: Hispanic Society of America, 1957), 18. For a discussion of the painted representation of a tirāz textile in the frescoes at San Isidoro de León, see Chpt. 7 by Pamela Patton in this volume.

30 The Museo Diocesano de Barbastro-Monzón is currently undertaking a study of the twenty-two lipsanothecas in its collection. While the objects come from churches in Alto Aragón, we expect that this pioneering study will shed light on this widespread Iberian practice. I am grateful to María Puértolas, Assistant Director of the Museo Diocesano de Barbastro-Monzón, for sharing preliminary information with me.

31 Juan Francisco Esteban Lorente and Manuel Santiago García Guatas, "Noticias sobre el hallazgo de un tejido musulmán," Artigrama 3 (1986): 29-34; Cristina Partearroyo Lacaba, "Estudio histórico-artístico de los tejidos de al-Andalus y afines," Bienes Culturales. Revista del Instituto del Patrimonio Cultural Español 5 (2005): 37-74, esp. 5o; Cristina Partearroyo Lacaba, "Textile Fragment," in Al-Andalus: The Art of Islamic Spain (New York: The Metropolitan Museum of Art, 1992), 226-228.

32 The textile from Arlanza is one of the earliest extant medieval textile objects found in the Iberian Peninsula, yet it is one of the least known and remains all but unstudied. There is a real possibility that this object is of Egyptian manufacture, although Carmen Bernis sees an "inspiración copta" and Florence May suggests that, while it shows "much dependence on Egyptian motifs, forms current at Córdoba had already been incorporated into the decorative scheme of textiles." Bernis, "Tapicerías hispano-musulmanas," 202; May, Silk Textiles, 18.

33 On the debate and possible falsification in the eleventh century of the foundational documents of San Pedro de Arlanza, see Manuel Zabalza Duque, Colección diplomática de los Condes de Castilla. Edición y comentario de los documentos de los condes Fernán González, García Fernández, Sancho García y García Sánchez (Salamanca: Junta de Castilla y León, 1998), 114-130. See also María del Carmen León-Sotelo Casado, "Formación y 
remained the most powerful Castilian monastery throughout the central Middle Ages. Not coincidentally, the status of the monastery at Arlanza guaranteed multiple visits and donations from Fernando I of León-Castilla, who had initially chosen it for his burial place before agreeing to Sancha's request that they both be buried at San Isidoro in León. ${ }^{34}$

To successfully locate the wealth of cult objects that circulated around the city of León and in the monastery of San Isidoro in the late eleventh century, it is necessary to cast a far wider net than the fated year 1063. We must think of the city of León starting in the mid-tenth century, at the time of repopulation that followed its establishment as the capital of Astur-León by Ordoño II (d. 924), when it was busy rebuilding itself as a Christian city and royal capital, constructing and endowing temples and monasteries, and filling them with textiles and objects associated with foundational treasures in the manner outlined above. ${ }^{35}$ The church at which the relics of Isidore were deposited was not the first temple to be built on the site. ${ }^{36}$ Perhaps in the late tenth century, a monastery consecrated to Saint John the Baptist had been erected over Roman remains. In the 105os Fernando I began a building campaign there to accommodate royal burial. Like the relics, the liturgical objects that pre-dated the reconstruction of the temple and the royal gift of 1063 may have simply been stored and reincorporated to fill the ritual needs of the renovated space. ${ }^{37}$

During the tenth century, there is increasing documentary evidence for textile gifts and woven goods in church inventories throughout northern Iberia, from Asturias to León and Castile to Galicia. In the eleventh century, textile

primera expansión del dominio monástico de San Pedro de Arlanza. Siglo X," En la España Medieval 1 (1980): 223-236; Julio Escalona Monge, Pilar Azcárate Aguilar-Amat, and Miguel Larrañaga Zulueta, "De la crítica diplomática a la ideología política. Los diplomas fundacionales de San Pedro de Arlanza y la construcción de una identidad para la Castilla medieval," in Actas del VI Congreso Internacional de Historia de la Cultura Escrita (Libros y documentos en la Alta Edad Media. Los libros de derecho. Los archivos familiares), ed. C. Sáez Sánchez (Madrid: Calambur Editorial, 2002), 2:159-206.

34 Viñayo González, Fernando I, 85.

35 On this topic, see Ana Rodríguez, "À propos des objets nécessaires. Dotations monastiques et circulation d'objets au royaume de León dans le haut Moyen Age," in Objets sous contrainte. Circulation et valeur des choses au Moyen Âge, ed. Laurent Feller and Ana Rodríguez (Paris: Publications de la Sorbonne, 2013), 63-89.

36 For the history of the site prior to the construction of the Romanesque church, see Therese Martin, Queen as King: Politics and Architectural Propaganda in Twelfth-Century Spain (Leiden: Brill, 2006), esp. 34-49.

37 In Chpt. 4 of this volume, Ana Cabrera also suggests the possibility of the movement of precious textiles from Asturias to León in the eleventh century. This is a provocative idea that requires archival corroboration. 


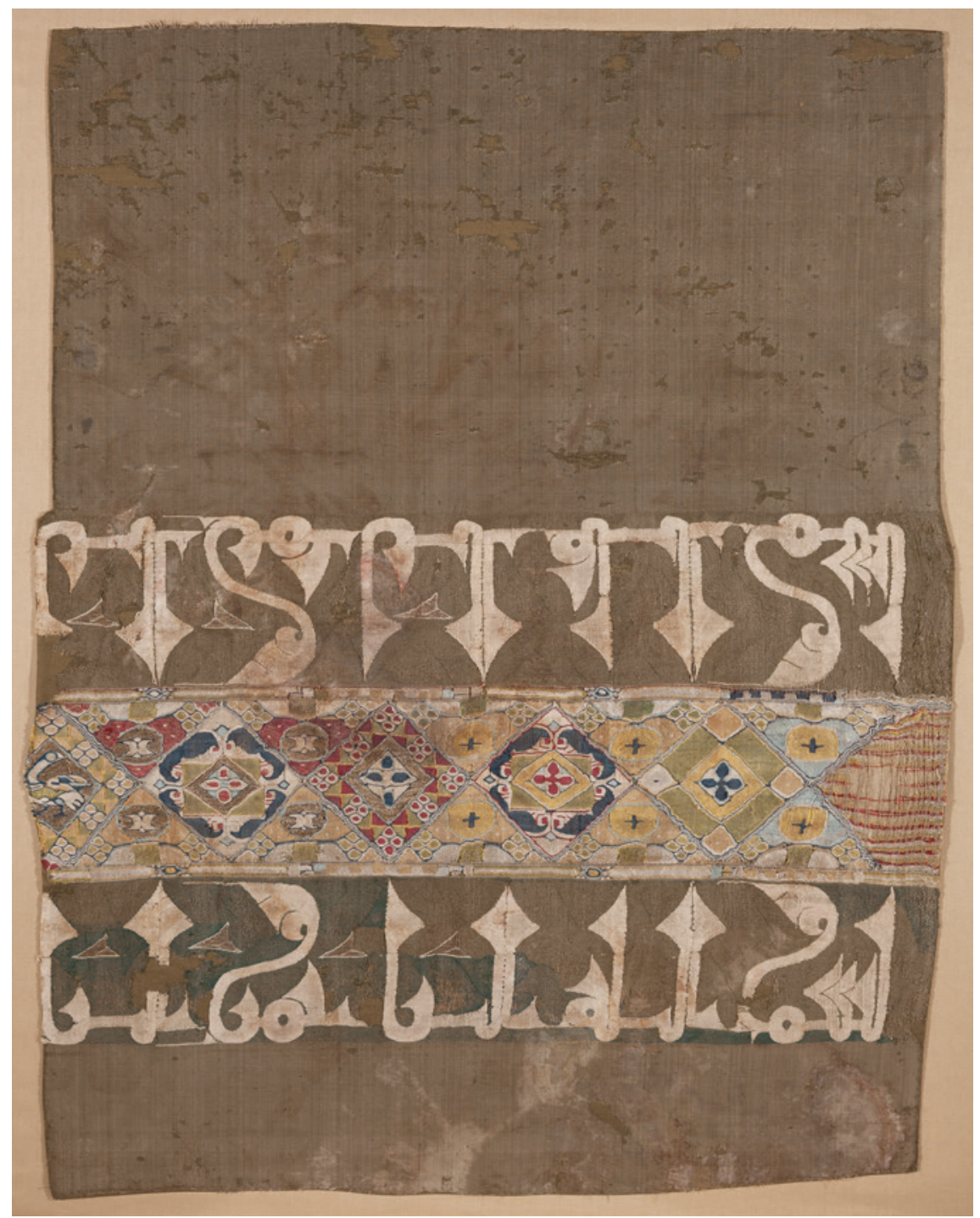

FIGURE 5.3 Textile fragment from Colls, 11 th century. Silk and gold thread, $51.8 \times 58.5 \mathrm{~cm}$. (Inv. No. 1542, Museo de Huesca).

donations reach an apogee. ${ }^{38}$ The written record offers evidence of geographic distribution that dovetails with the possible origins of the extant textiles at San

38 The foundational texts focused on documentary evidence pertaining to material culture are Sánchez-Albornoz, Una ciudad; Sánchez-Albornoz, "El precio de la vida en el reino asturleonés hace mil años," Logos 3 (1944): 225-264; Gómez-Moreno, Iglesias mozárabes; 
Isidoro. In addition to the frequent references to Byzantine textiles (greciscos), the allusions to Persian goods are notable. There were duzuries, an unidentified descriptor that may be geographic, perhaps referring to the Persian term douzī, or embroidery. ${ }^{39}$ The term ferucílferucies in conjunction with textiles confounded earlier historians, although it closely recalls the word farsi, or Persian. ${ }^{40}$ Interestingly, the texts use this word to refer to a type of cape (manto) or large length of cloth that can be associated with the products of medieval Persian zilu looms, whose considerable size required two weavers working side by side. The best-preserved evidence of the circulation of these products in medieval Iberia is the spectacular blue silk with white double-headed eagles or griffins, found at the monastery of San Zoilo in Carrión de los Condes: this cloth measures an impressive $2.75 \times 2.08 \mathrm{~m} .{ }^{41}$ Of course, there were also maurescos, textiles from al-Andalus or possibly from the looms of Mozarabic țirāz weaving communities that cropped up after the dissolution of caliphal power in the early eleventh century. The town of Pajareros at the southernmost frontier between León and al-Andalus had a community of "muzarabes del rex tiraceros."

Manuel Gómez-Moreno, Catálogo monumental de España. Provincia de León, 2 vols. (Madrid: Ministerio de Instrucción Pública y Bellas Artes, 1906-19o8); Luis García de Valdeavellano, "El mercado. Apuntes para su estudio en León y Castilla durante la Edad Media," Anuario de Historia del Derecho Español 8 (1931): 201-403. The appendix in Manuel Risco's pioneering work on León also contains important references to eleventh-century textiles in the churches of León. Manuel Risco, España Sagrada. Memorias de la Santa Iglesia de León, Tomo xxxvi (Madrid: Oficina de Blas Román, 1787).

39 Serrano-Piedecasas conflates the terms loztou, doztoní, and ducerí, identifying them as a geographical type from "la provincia de Juzistán, de la ciudad de Dastuwa. Tela listada." However, the term ducerí, closer to douzi, might also refer to a Persian embroidery. The term still used all over the Persianate world to generically designate an embroidery. Malileh douzī, for instance, is a highly desirable embroidery made with metallic thread, which has a long history in the Persian world. Zardozi, or zar douzī, is a gold embroidery technique practiced in Iran, Pakistan, and India. Regardless, a clear allusion to Persian textiles is evident here. Luis María Serrano-Piedecasas Fernández, "Elementos para una historia de la manufactura textil andalusí (sigl os IX-XII)," Studia Historica. Historia Medieval 4 (1986): 205-227, esp. 225.

40 Sánchez-Albornoz, Una ciudad, 101, n. 94.

41 This piece was identified recently as the product of a zilu loom. See Pilar Borrego, Silvia Saladrigas, and Miguel Ángel Andrés Toledo, "Technical and Symbolic Study of Two Complete Medieval Cloths Found in Carrión de los Condes, Spain," in Purpureae Vestes V: Textiles, Basketry, and Dyes in the Ancient Mediterranean World, ed. J. Ortiz et al. (Valencia: Universidad de Valencia, 2016), 163-170. See also José Luis Senra, "Dos telas islámicas encontradas en el monasterio de San Zoilo de Carrión de los Condes," Goya 203 (2004): 332-340.

42 As cited from Catedral de León, Tumbo I, fol.154 in Gómez-Moreno, Iglesias mozárabes, 117. See also Richard Hitchcock, Mozarabs in Medieval and Early Modern Spain: Identities and 
While Pajareros is the only such town of which we have written notice, it is not far-fetched to think that other skilled weavers also made their way north.

Returning to the theme of reuse, a document dated 1073 from the Cathedral of León details an inventory of goods that Bishop Pelayo acquired during his tenure as part of the restoration and consecration of the temple. ${ }^{43}$ According to Bishop Pelayo, after the destruction of the city of León and the profanation of its churches during the razzias of al-Mansur in the late tenth century, it took almost a century for the cathedral to regain the dignity of its episcopal stature. ${ }^{44}$ The cathedral was rebuilt, refurbished, and re-consecrated. The 1073 document lists a great number of newly purchased textiles: multiple greciscos, other cloths embroidered or tapestry woven, perhaps in gold (morgomes), ${ }^{45}$ made of scarlet (ciclatun), linen (bissino), and striped textiles of various kinds. ${ }^{46}$ However, the most revealing information comes from the Bishop's declaration: "And I restored many garments that had been worn out due to their age, on which more was spent than on those which I [had] made from

Influences (Aldershot: Ashgate, 2008), 69-74; María Judith Feliciano, "Medieval Textiles in Iberia, Studies for a New Approach," in Envisioning Islamic Art and Architecture. Essays in Honor of Renata Holod, ed. David Roxburgh (Leiden: Brill, 2014), 46-65, esp. 55, n. 37.

43 See José Manuel Ruíz Asencio, Colección documental del Archivo de la Catedral de León, 19 vols. (León: Centro de Estudios e Investigaciones San Isidoro, 199o), 4:439-447. I am grateful to Lucy Pick for sharing this document with me. For the Romanesque cathedral, see Gerardo Boto, La memoria perdida: la catedral de León (917-1255) (León: Diputación Provincial de León, 1995).

44 "Post cuius mortem, non paucis annis transactis, gens perfida hismahelitarum et pene similis antiquis cultoribus idolorum insurrexit contra christicolas, destruxit ecclesias, subuertit altaria, contaminauit sancta; depopulata est et redegit in suum ius totam provintiam; interea cotingit hanc sedem deprauari et contaminari et fuit sine honore multis annis, id est, usque ad tempora regis Adefonsi et regis Santii, patris dompni Fredenandi superius nominati, qui me ibidem preposuit ... sedem non ualuerunt ad perfectum mundare sancta que polluta fuerant neque diem consecrationis siue restaurationis institutere, sicut mos est pre multitudine bellorum, usque ad presens tempus." José Manuel Ruiz Asencio, Colección documental del Archivo de la Catedral de León (775-1230) (León: Centro de Estudios e Investigación "San Isidoro", 1990) IV:442.

45 Jaime Varela Sieiro, "Tejidos y vestimenta de procedencia árabe en la documentación altomedieval gallega," in Tejer y vestir: De la antigüedad al islam, ed. Manuela Marín (Madrid: Consejo Superior de Investigaciones Científicas, 2001), 255-286, esp. 279.

46 “... et duas stolas argenteas et aliam auro fresam, quibus inieci manipulos greciscos, et duas dalmaticas greciscas et unam ciquilatonem et duos morgomes, et unum frontalem dolceri et concam iragam et tunicam cardinam cum suis listis et casullam bissinam et duas stolas albas cum suis manipulis et unum amictum morgome et viii mantos lineos et xii alvas lineas et tres casullas cum suis tunicis et amictis et unum corporale de bisso et omnia uestimenta linea ad altaria operienda." Ruiz Asencio, Colección documental, 443 . 
scratch." ${ }^{\prime 7}$ The description of these old textiles suggests that these were items that likely survived the razzias. As discussed above, relics and cult objects were routinely hidden away during violent times. Their tales of survival only added to the reputation of the object as essential to the local geography of the sacred. ${ }^{48}$

Because of the price and preciousness of luxury textiles, in addition to their association with ritual and antiquity, once sacralized, they were used until they were simply too damaged and indecorous to be ritually appropriate. Even then, as an image from the early twentieth century taken by the photographer Adolf Mas in Serradui (Huesca) demonstrates, a sliver of an ancient textile would still be kept as a shard of sanctity (Figure 5.4). That notion helps to explain the small and fragmentary state of several textiles at San Isidoro. For instance, a photograph taken around 1931 seems to suggest - we cannot be sure- that the objects might have been found inside the Limoges-style enamelwork casket (Figure 5.5). Today the large textile visible on the right survives only as a minuscule sliver (perhaps the rest has been put back into the now-locked casket?), while the one sewn into a bag, which can be seen on the left, has since been taken apart and laid out for display. ${ }^{49}$ Nevertheless, we can see that the final chapter in the ritual life of these two textiles was as relic wrappers. In their previous lives they were likely curtains, antependia, or vestments.

The treasury of San Isidoro has representative pieces of nearly every type of woven good mentioned above. Of the Andalusi or Mozarabic manufactures, it holds at least two possible samples, the lining of the Casket of Saints John the Baptist and Pelayo (Figure 5.6) and the well-known fragment with eled phants surmounted by lions and birds (Figure 5.7). The prominent inscription in the fragment of the elephants would appear to indicate a foreign manufacture, reading on the top circle البركة من الله و اليمن (al-baraka min Allah wa

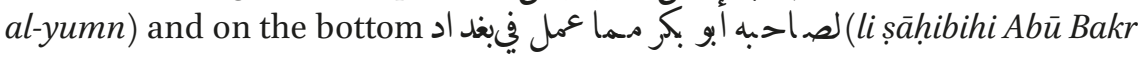
mimma 'umila fi Baghdād); that is, "blessings from God and prosperity to the owner Abu Bakr, from those [objects] made in Baghdad."50 Yet the inscription

47 "Et restauraui plurima indumenta que erant uetustate consumpta, in quibus maior expensa est quam in his que de nouo operatus sum ..." Ruiz Asencio, Colección documental, 443. I am grateful to Therese Martin, Eduardo Fernández, Kenneth Baxter Wolf, and Lucy Pick for revising and correcting the translation.

48 Conversely, the powerful presence of Leonese relics in Oviedo became embedded in the myth of the city as a refuge of sanctity for generations. See Alonso Álvarez, La Cámara Santa, $75^{-77}$.

49 See Table 1, no. 4 in Chpt. 4 by Ana Cabrera in this volume.

50 Rhuvon Guest read “Abu Nașr" instead of "Abū Bakr." Like Gómez-Moreno, I discern a clear kāf, instead of a șād. My thanks to Nourane Ben Azzouna for corroborating the epigraphic 


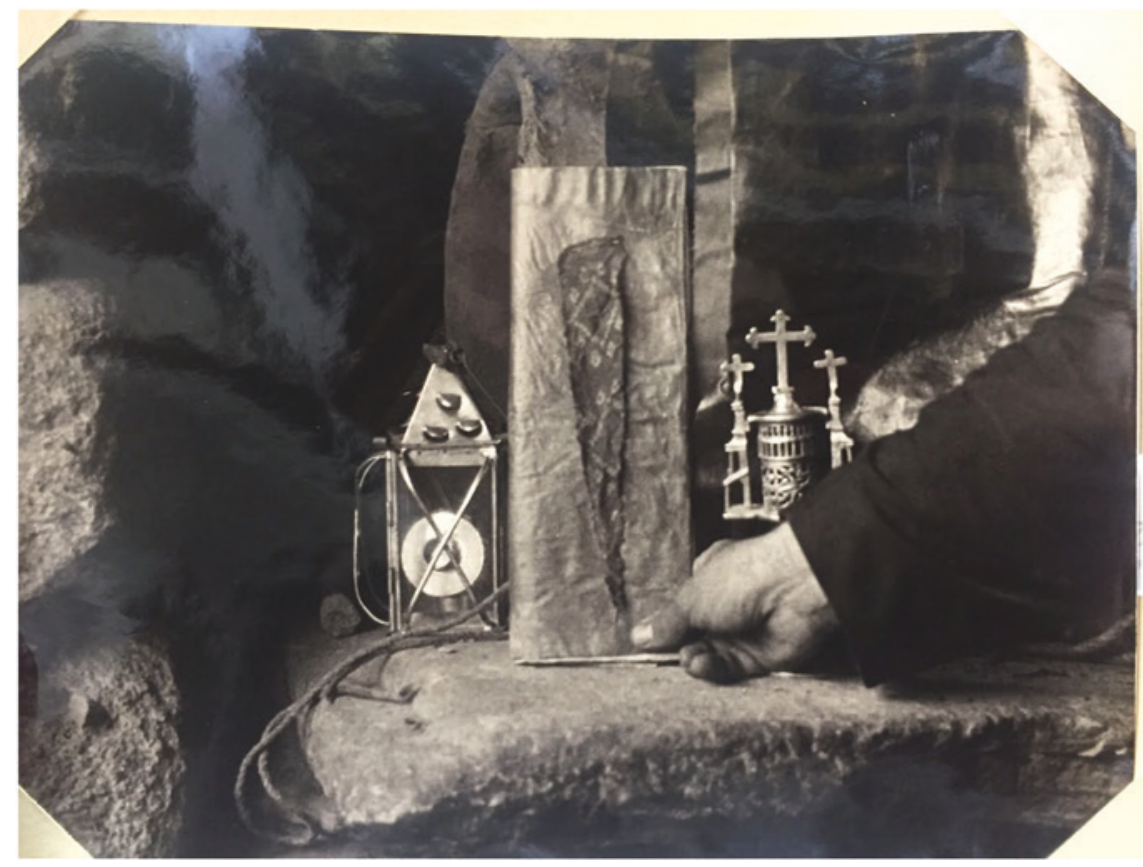

FIGURE 5.4 An assortment of liturgical treasures from Serradui, Huesca.

PHOTO: ADOLF MAS, (C) ARXIU MAS/INSTITUT AMATLLER D'ART HISPÀNIC

appears to be misleading, as the technical aspects of the textile indicate that it may have been woven in the Iberian Peninsula. ${ }^{51}$ At El Burgo de Osma, another Iberian textile with a similar inscription, which has been associated with the burial of San Pedro de Osma (1040-1109), is perhaps the best-known example of baldaquíes, or Baghdadi textiles. The inscription from El Burgo de Osma famously reads هاذا مـما عمل فيبغ اد حرسه اله (hādhā mimmā 'umila fi Baghdād harasaha Allāh), or "this is from those [objects] made in Baghdad, may God protect her" (Figure 5.8). Because both textiles refer to Baghdad directly, rather than to Madinnat as-Salām as did early 'Abbasid sources, we can also ascertain that they are not dated before the eleventh century. Unlike in ceramics, metalwork, and other media from medieval Islamic periods, it is not common to find a textile inscription that mentions no more than the name of a non-elite

reading. See Albert Frank Kendrick and Rhuvon Guest, "A Silk Fabric Woven at Baghdad," Burlington Magazine 49 (1926): 261-267; Gómez-Moreno, Catálogo monumental, i:166.

See Ana Cabrera's contribution to this volume, Chpt. 4. 


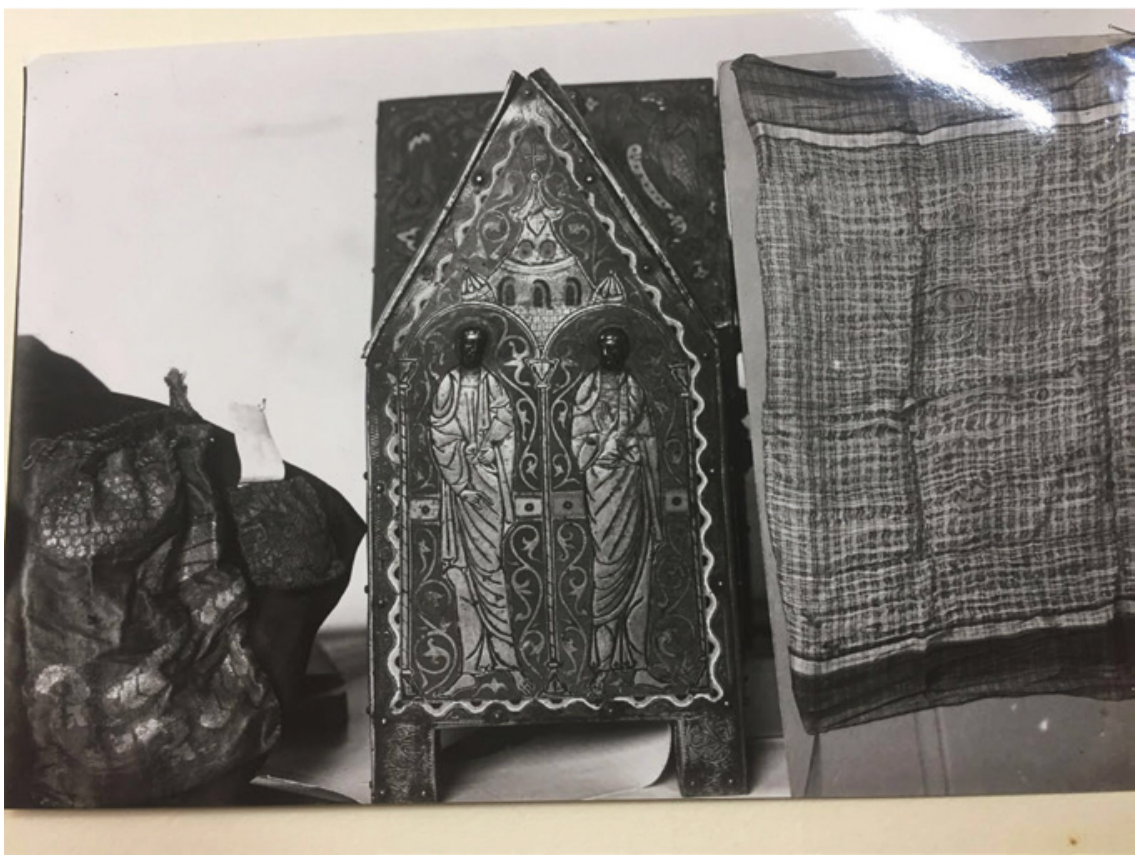

FIGURE 5.5 Textiles with enamel casket, photographed ca. 1931 (Museo de la Real Colegiata de San Isidoro de León, Inv. No. IIC-3-089-002-0oo3). See also Fig. 1.2.

PHOTO: ADOLF MAS, (C) ARXIU MAS/INSTITUT AMATLLER D'ART HISPÀNIC

"owner" (in the case of the Isidoran fragment, an untitled man named Abū Bakr). Usually, when textiles bear names, they are also inscribed with the titles of rulers, and the royal manufacture (dar al-tiräz) may be identified and a date given. Can we think of Abu Bakr, then, as the weaver, the cartoon designer, or the owner of the workshop?52 Or was the inscription copied blindly from an existing cartoon in the workshop? Another problem for determining the origin of the textile is the fact that no archaeological examples survive from 'Abbasid Baghdad. Given the different types of textiles that claim to be Baghdadi goods, it is also difficult to identify with precision exactly what the Iberian workshops that produced these silks were attempting not just to imitate but indeed to pass off as the real thing. The baldaquies, therefore, emerge as an exceptionally unstable category.

$5^{2}$ Guest suggested that the name might refer to the weaver, but there are various possibilities. Kendrick and Guest, "A Silk Fabric," 267. 


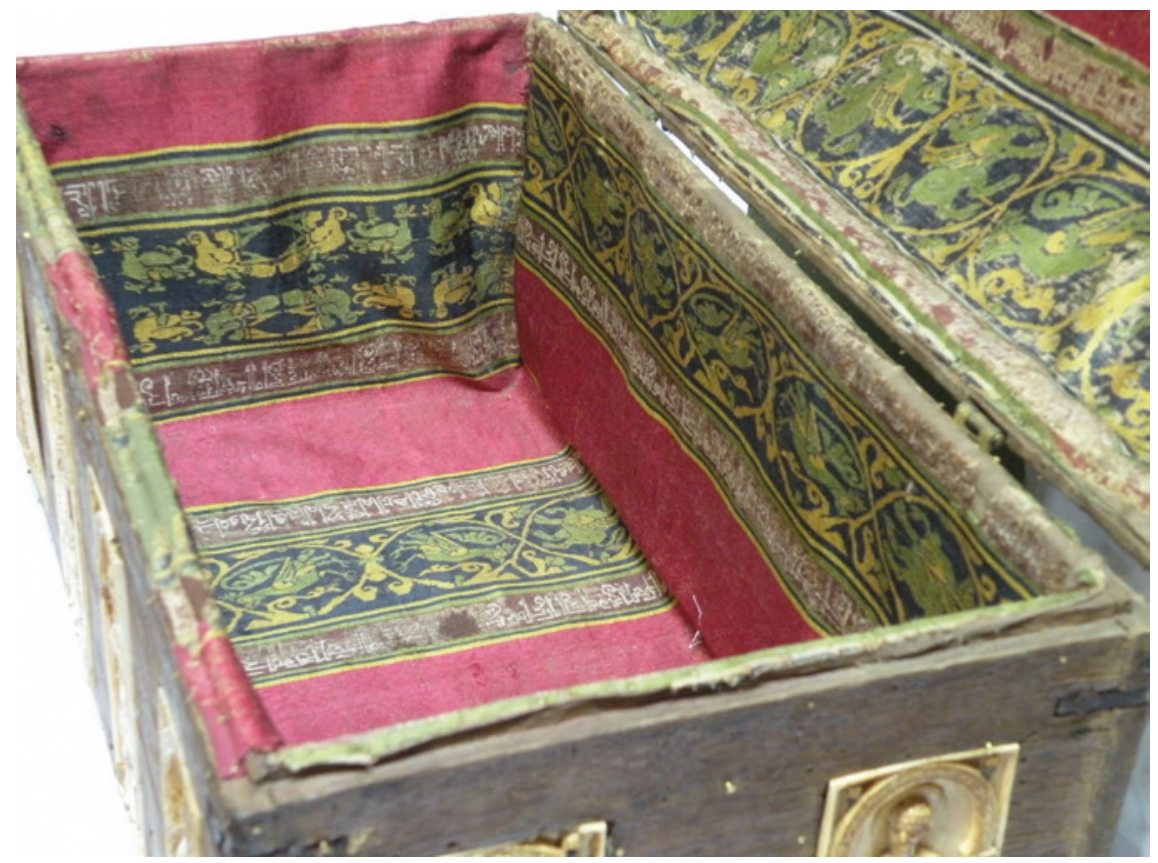

FIGURE 5.6 Lining of the Casket of Saints John the Baptist and Pelayo (Museo de la Real Colegiata de San Isidoro de León, Inv. No. IIC-3-089-0o2-0o23). See also 1.8, 4.12a, $4.12 \mathrm{~b}, 5 \cdot 9,6.7 \mathrm{a}, 6.7 \mathrm{~b}$.

PHOTO: ANA CABRERA

The second textile of possible Iberian manufacture at the treasury of San Isid oro is the lining in the reliquary casket said to have held the remains of John the Baptist and Pelayo. Like the baldaquies mentioned above, this silk weaving presents technical similarities with Andalusi products. ${ }^{53}$ Epigraphii cally, the Arabic is difficult to ascertain because it is riddled with spelling mistakes (Figures 5.6 and 5.9). It reads ازز لموبد نا الملك (izz li mawabdnā al malik) in an attempt to write عزلمولانا الملك (iz li mawlānā al-malik) or "glory to our lord the king." ${ }^{54}$ The technical aspects of the weave, the imperfect Arabic, and the variation on the traditional "iz li mawlānā as-sulțān" (glory to our lord the sultan) or "iz li mawlānā as-sulțān al-malik" (glory to our lord the reigning sultan) should make us receptive to the idea that this textile may be a local

53 See the contribution by Ana Cabrera to this volume, Chpt. 4.

54 Ahmed Mahmoud Dokmak and Zeinab Shawky Sayed, "Aportaciones de la epigrafía árabe en el arte románico español. Una faceta de la cultura árabe-islámica medieval," Un Mundo, Muchas Miradas 4 (2015): 109-133, esp. 115-116. 


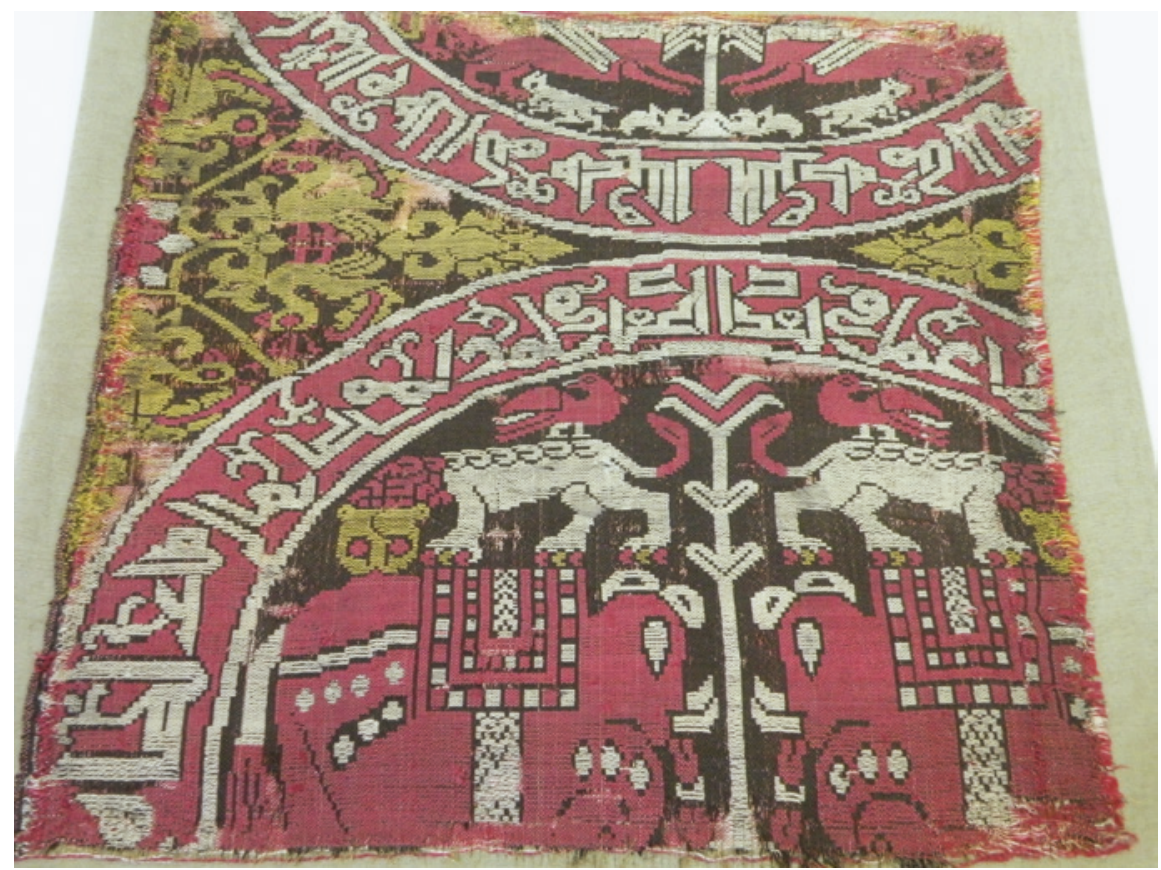

FIGURE 5.7 Elephant fragment or so-called Baghdad Silk (Museo de la Real Colegiata de San Isidoro de León, Inv. No. IIC-3-089-002-0028). See also Figs. 4.2a, 4.2b. PHOTO: THERESE MARTIN

product, possibly made by Mozarabic weavers. ${ }^{55}$ While there is no evidence to affirm that the term Mozarab was widely used in the twelfth century, its earliest documented use in 1024 ("muzarabes de rex tiraceros") suggests a royal effort to recruit highly skilled Christian weavers from Córdoba of various levels of cultural and linguistic affinity with the dominant Caliphal society. ${ }^{56}$ Such degrees of acculturation (and, thus, of Arabic language literacy) might explain the poor written Arabic on the textile.

Yet, there is a crucial lack of reliable comparanda against which to measure the possible Mozarabic textile that lines the reliquary of John the Baptist and Pelayo.

55 More than a century ago, Gómez-Moreno maintained that this textile "se haría aquí, en España, y aún acaso por tiraceros mozárabes.” Gómez-Moreno, Catálogo monumental, I:166.

56 As Hitchock argues, "these tiraceros may, then, have been called muzaraves simply to indicate their provenance. That they were so called is neither an indicator of their religion nor necessarily of their Arabization. It was nothing more than a pointer to their place of origin." Hitchcock, Mozarabs in Medieval and Early Modern Spain, 69-75. 

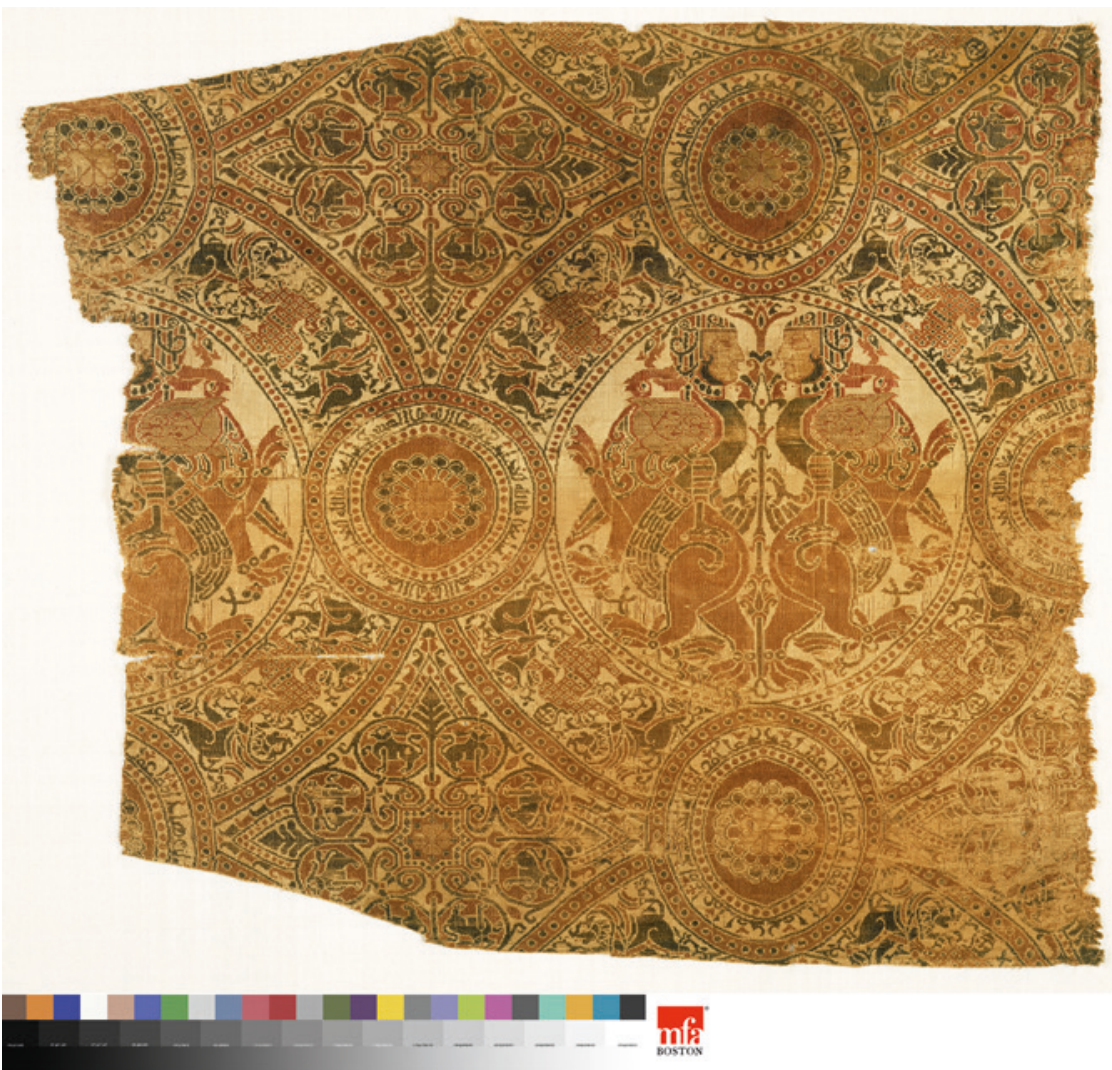

FIGURE 5.8 Textile fragment with wrestling lions and harpies from the tomb of Pedro de Osma. Spain, probably Almería, early 12th century. Silk lampas with supplementary discontinuous metal-wrapped patterning wefts, $50 \times 43 \mathrm{~cm}$. (Boston, Museum of Fine Arts, 33.371. Ellen Page Hall Fund). PHOTO: (C) MUSEUM OF FINE ARTS, BOSTON

For instance, although the combination of elements in this silk seem to indicate that Gómez-Moreno was right to identify it as Mozarabic, his assignment of a veil from San Pedro de Montes in El Bierzo to Mozarabic manufacture on stylistic grounds alone is more arbitrary: "a beautiful cloth where there are segments woven in tapestry technique, in linen and in silk, and in the geometric decoration there is a combination of whites and blues, yellow, greens and reds." ${ }^{57}$ We simply do not know how a textile produced in a Mozarabic țirāz workshop differed aesthetically from any other produced elsewhere on the Iberian Peninsula. 


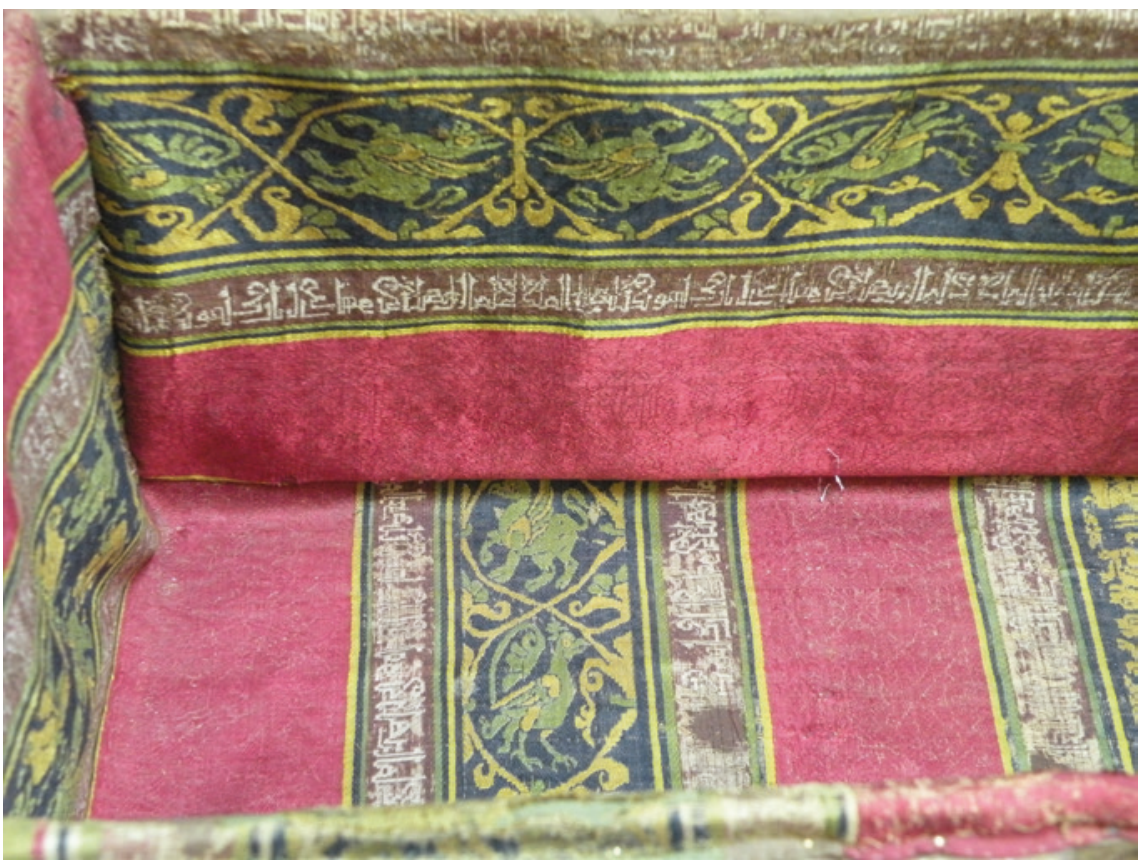

FIGURE 5.9 Detail, textile from the reliquary of Saints John the Baptist and Pelayo (Museo de la Real Colegiata de San Isidoro de León, Inv. No. IIC-3-089-002-0023). See also $1.8,4.12 \mathrm{a}, 4.12 \mathrm{~b}, 5.6,6.7 \mathrm{a}, 6.7 \mathrm{~b}$.

PHOTO: ANA CABRERA

At the treasury of San Isidoro, no textile exemplifies the themes of use, reuse, antiquity, and royal and historic memory in the medieval urbe regia of León better than the enigmatic cloth popularly associated with the reliquary of San Marcelo/San Claudio (Figure 5.10). Despite the poor conservation state of this exceptio nally rich textile, it is evident that the fragments of the blue and white silk once functioned as the lining of a large reliquary. ${ }^{58}$ In its elaboo rate and detailed pattern, at least two human figures can be made out: first, an elegantly dressed male standing in front of an animal, knife in hand, inside a roundel surrounded by an inscription in Arabic (Figure 5.11). It is difficult to dei termine the complete epigraphic content because of the loss of material, but the word بركة.(baraka), or blessing, is clearly distinguishable inverted in mirror effect. The seeming assortment of meem and lām consonants might suggest a

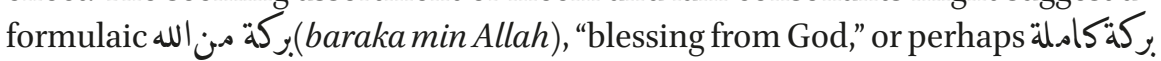
(baraka kämila), "perfect/total blessing." The second figure is an elegant lady

$5^{8}$ For dimensions and detailed technical analyses, including dating, see Chpt. 4 by Ana Cabrera in this volume. 


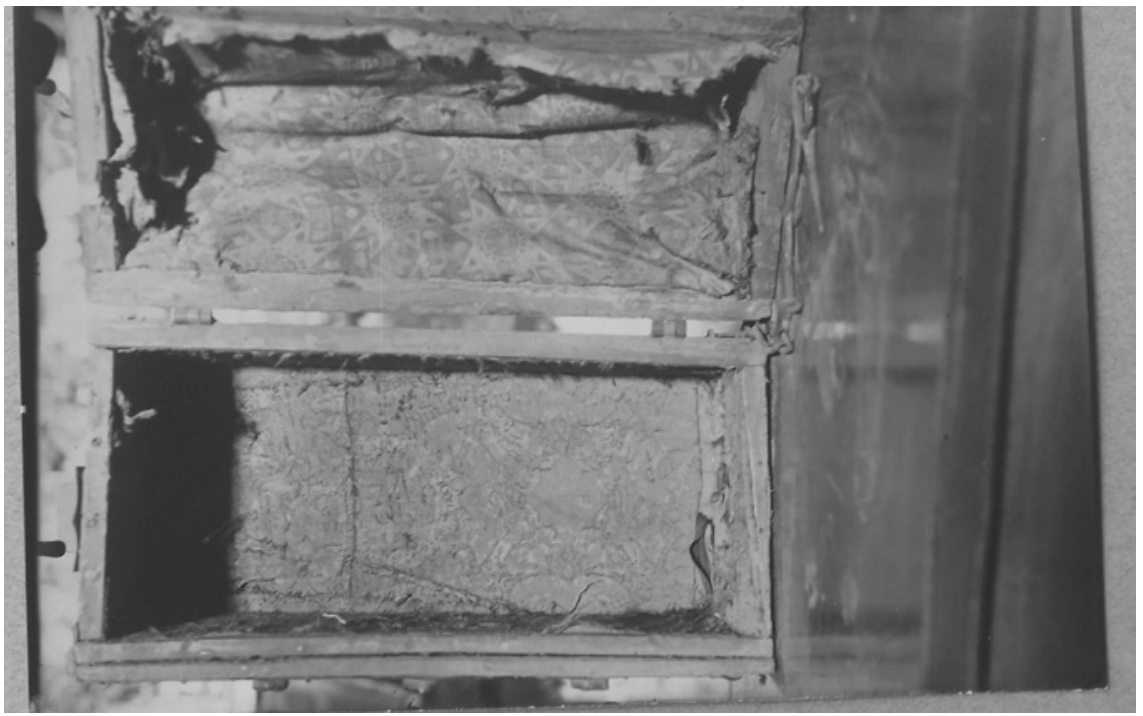

FIGURE 5.10 Reliquary of San Marcelo/San Claudio, early twentieth-century photograph, with textiles still in situ (Museo de la Real Colegiata de San Isidoro de León, Inv. Nos. 3-089-0о2-0025, о०26, о०33, о०34, о०35, о०36, о०37, о०38). See also Figs. 4.11, 4.13, 5.11, 5.12.

PHOTO: ARCHIVO GÓMEZ-MORENO, CSIC

wearing a crown and long pearl earrings while riding side-saddle on a beast (a lion or a horse), also within a roundel surrounded by an Arabic inscription that is yet more difficult to discern (Figure 5.12). The words بركة من / بركة و baraka min /baraka wa), or "blessings from / blessings and" are faintly legible.59 The exceedingly complex decorative patterns surrounding the figures include interlocking polylobed medallions, seven-pointed stars, flowers, pearl strings, geometric fillers, and small griffins, making it one of the most technically advanced and intricate textiles in the treasury. Carbon-14 analysis dates this silk between AD 968-1046, predating the royal endowment of 1063 at San Isidoro, and it may indicate a Persian or Eastern Mediterranean manufacture. ${ }^{60}$

59 Gómez-Moreno rightly recognized the word baraka in this textile, but he suggested as a possible reading the unpersuasive "bendición saludable" or "healthful blessing." GómezMoreno, Catálogo monumental, 169 .

6o See Table 1 at the end of Chpt. 4 by Ana Cabrera in this volume. For his part, GómezMoreno, Catálogo monumental, 169, was stunned by the beauty of the object: "La perfección y habilidad de esta obra y su belleza sorprenden." He suggested a twelfth-century date and a Persian origin. 


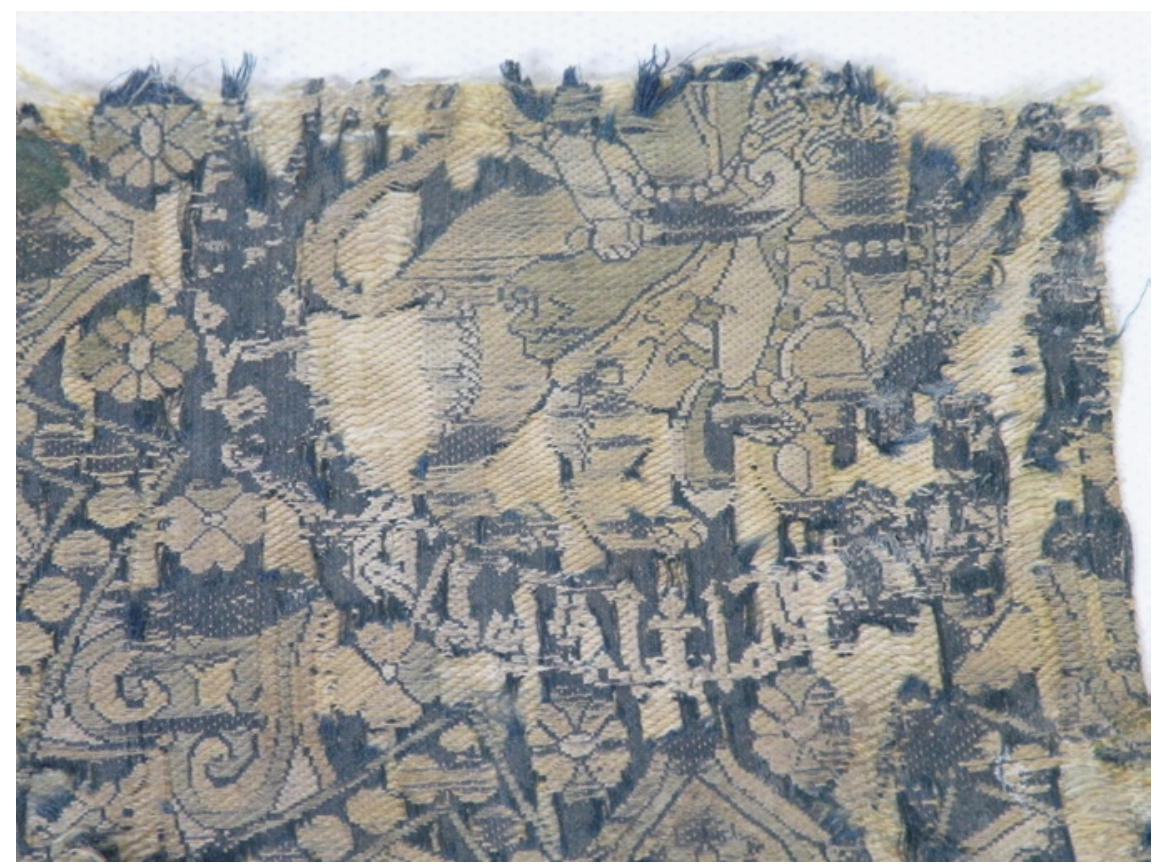

FIGURE 5.11 Detail of San Marcelo/San Claudio silk, showing a standing male figure with a knife (Museo de la Real Colegiata de San Isidoro de León, Inv. Nos. 3-089-oo2o.25, o०26, o०33, о034, o035, о036). See also Figs. 4.11, 4.13, 5.10, 5.12. PHOTO: THERESE MARTIN

At the turn of the twentieth century, Manuel Gómez-Moreno saw the fragments of this textile still attached to an unremarkable pine wood reliquary that he identified as "perhaps having contained in the Monastery of San Claudio the relics of the saint himself and of his brothers Lupercio and Victorio, donated by Cardinal Jacinto, Papal Legate, in 1173."61 This identification is still in use at the Museo de San Isidoro. Yet, our research unearthed an early twentiethcentury photograph of the reliquary's bottom panel that identifies it clearly as "San Marcelo" (see Figure 5.10).62 The path to clarify the proper identification of the one of the most sophisticated textiles in the treasury of San Isidoro takes us beyond the Colegiata itself, the city of León, and even the medieval period.

61 The attribution is found in Gómez-Moreno, although the author did not document or explain how he reached this conclusion: "Arqueta que contuvo reliquias en el Monasterio de San Claudio, acaso los de este mismo santo y de sus hermanos Lupercio y Victorio, donados por el Cardenal Jacinto, Legado Pontificio, en 1173." Gómez-Moreno, Catálogo monumental, 169 .

62 My thanks to Ana Cabrera for sharing the image with me. 


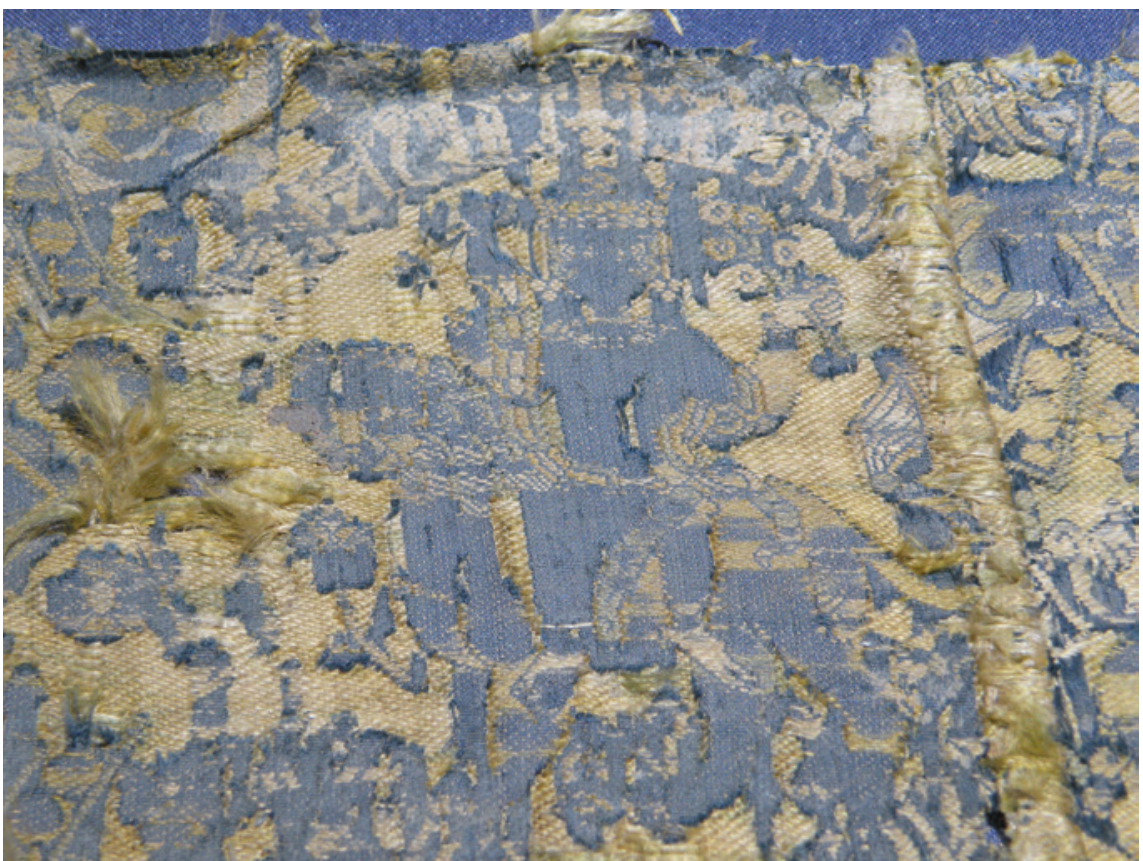

FIGURE 5.12 Detail of San Marcelo/San Claudio silk, showing a female figure on a beast

(Museo de la Real Colegiata de San Isidoro de León, Inv. Nos. 3-089-002-0025, оо26, о०33, оо34, оо35, оо36). See also Figs. 4.11, 4.13, 5.10, 5.11.

PHOTO: THERESE MARTIN

Father and son, Marcelo and Claudio are Leonese saints long venerated in the city. San Marcelo was a Roman centurion beheaded in the third century in present-day Tangiers for publicly refusing to bear arms and military insignia, following Christian dogma. ${ }^{63}$ Towards the beginning of the ninth century, there was already a church of San Marcelo in León, built on the site of his confession, which was subsequently rebuilt in 1096 along with the Hospital of San Marcelo, one of the earliest medieval pilgrims' hospitals in León. ${ }^{64}$ The remains of his son Claudio, martyred by the sword in the year 303 as a result of Diocletian's persecution of Christians, remained in León at the monastery of

63 Michael Kulikowski, Late Roman Spain and Its Cities (Baltimore: Johns Hopkins University Press, 2004), 218; Alfonso García Gallo, "El proceso de San Marcelo de León," in Estudios en Homenaje a Don Claudio Sánchez-Albornoz en sus go Años (Buenos Aires: Instituto de Historia de España, 1983), 1:281-29o; Giuliana Lanata, "Gli atti del proceso contro il centurione Marcello," Byzantion 42 (1972): 509-522.

64 José González, Vida de San Marcelo (Madrid: Blass SA Tipográfica, 1943), 90-91. 
San Claudio, built on the site of his martyrium. ${ }^{65}$ In the year 1173, his body was translated from the crypt of the church to the high altar. The earliest extant document that includes an inventory of the relics at San Isidoro, dated 1331, bears witness to the presence of relic fragments of San Claudio and his brothers in the treasury. Perhaps small remains were translated to San Isidoro when the relics were moved in the twelfth century. ${ }^{66}$

Unlike San Claudio's remains, San Marcelo's relics were absent from León for more than a thousand years. It was during the conquest of Tangier in 1471 by Alonso de Portugal that the remains of the Leonese centurion were located, and in 1493 they were sent to León, escorted by Diego Diez de Isla, a member of the cathedral chapter and abbot of San Marcelo. ${ }^{67}$ In the same year on 29 March, León briefly became an urbe regia again, a status it had lost following the death of Alfonso IX in 1230. More than two hundred years later, King Ferdinand of Aragon traveled to the city to receive the relics of Marcelo, escorted by his soldiers and surrounded by members of the highest echelons of Iberian aristocracy, which included the Constable and Admiral of Castile, the Count of Luna, and the Viceroy of Galicia, among others. The relics of the saint were carried in a palanquin covered by "un brocado muy rico" - a rich brocade- through the streets of León, pausing at the church of San Claudio where father and son were briefly reunited while the procession waited for the king to finish mass in the cathedral. Lastly, the king himself saw the body of the saint safely to its home in the church of San Marcelo. ${ }^{68}$

The year 1493 was enormously important in the consolidation of the sovereignty of the Catholic Monarchs, Ferdinand and Isabella. In fact, King Ferdinand stopped in León en route to Tordesillas from Barcelona, where he had met Christopher Columbus after his return from the second voyage to the Americas. After León, the king continued to Tordesillas, where the Bulas Alejandrinas were being negotiated with Portugal and the Papacy. The Americas and North Africa, the land where San Marcelo was martyred and from where his body was recovered, played a crucial role in the post-Granada geopolitical game of

65 Risco, España Sagrada, xxxiv:353-359.

66 For a detailed description of the inventory of indulgences and relics at San Isidoro, see Chpt. 2 by Therese Martin in this volume. I thank her for sharing this information with me.

67 Juan Croiset, Suplemento á la última edición del Año Christiano (Madrid: Imprenta de Joseph García, 1796), II:302-303; José García de la Foz, Crónica General de España. Crónica de la Provincia de León (Madrid: Rubio y Co., 1867), 71-72; González, San Marcelo, 95; Risco, España Sagrada, 256-26o. 
the Spanish monarchy. ${ }^{69}$ Twenty-two years had by then passed between the discovery of the relics in Tangiers and their translation to León. At this time, a large-scale reformation of the Iberian Church after the conquest of Granada occupied the sovereigns' attention. The spiritual and architectural landscape of the Iberian Peninsula was transformed under the Catholic Monarchs, and the theatrical setting of León as an urbs regia that imbued the monarchy with a link to the past by way of the cult of saints was activated, once again. ${ }^{70}$

By the end of the sixteenth century, the church of San Marcelo had fallen into disrepair. The temple underwent a major rebuilding campaign in 1586 and the relics were taken to the cathedral for safekeeping, against the wishes of the abbot of San Claudio, who felt strongly that the relics of father and son should be kept together. The work finished in 1628 and the relics returned to their home. ${ }^{71}$ In the nineteenth century, the history of the relics of San Marcelo and San Claudio became entangled almost beyond recognition. The political instability that defined the century caused a near constant movement of relics for safekeeping. First, the Napoleonic invasion of 1808 required that the relics be secured. In 1821, revolutionary violence prompted the return of the relics of San Claudio to the church of San Marcelo. In 1834, Claudio's relics were moved to San Marcelo permanently when the monastery of San Claudio was destroyed. ${ }^{72}$ The final blow seems to have come in 1868 when, at the insistence of José Amador de los Ríos, director of the newly founded Museo Arqueológico Nacional in Madrid, the parish priest of San Marcelo "donated" the Nasrid sword that had adorned the figure of the saint by the renowned sculptor Gregorio Fernández. ${ }^{73}$ The sword was popularly believed to have been a gift to San Marcelo from Ferdinand of Aragon, although the historical sources do not corroborate it. Of the reliquaries and the textiles nothing is heard again until Gómez-Moreno's publications in the early twentieth century, by which time yet one more step of displacement-from San Marcelo to San Isidoro—had taken place. Perhaps the move to San Isidoro was an attempt at safekeeping objects of artistic interest after losing the Nasrid sword to Madrid? Or perhaps the new

69 Álvaro Fernández de Córdova Miralles, “El 'Rey Católico’ de las Primeras Guerras de Italia. Imagen de Fernando II de Aragón y V de Castilla entre la expectación profética y la tensión internacional (1493-1499)," Medievalismo 25 (2015): 197-232, esp. 218.

70 Álvaro Fernández de Córdova Miralles, "El 'otro príncipe': Piedad y carisma de Fernando el Católico en su entorno cortesano," Anuario de Historia de la Iglesia 26 (2017): 15-70, esp. 26-29.

71 González, Vida de San Marcelo, 11-13.

72 González, Vida de San Marcelo, 131.

73 José Ferrandis Torres, "Espadas granadinas de la jineta," Archivo Español de Arte 16 (1943): 142-166, esp. 154-155. 
silver reliquary of San Marcelo rendered the old box obsolete and so it was sent to the treasury. It may be that the pine box with its silk lining once held San Claudio's remains and that the label identifying it as San Marcelo refers to the church of origin rather than the saint within. It is certain, however, that the reliquary of San Marcelo/San Claudio was not part of the royal donation of 1063 .

There is a last and important question to sort out in the tangled story of these relics: why would a tenth- or eleventh-century textile be used in the translation of relics of 1493 ? It is possible that, just as in medieval times, the recognizable antiquity of this textile, which may have either been present at the church or donated for the occasion, was deemed suitable for the purpose of honoring the Roman martyr. Perhaps the imagery on the textile of a figure with a weapon in hand was chosen to evoke San Marcelo, the Legionnaire, who both lived and was killed by the sword? Or perhaps it is more feasible to associate this silk either with San Claudio's ceremonial translation to the altar of his church in 1173 or with the arrival of his fragments in San Isidoro between then and 1331. In any case, the early modern and more recent history of the reliquary of San Claudio/San Marcelo further underscores the deep-rooted relationship between monarchy, urbe regia, and memory in the geographies of the sacred.

Scholarship on the material and spiritual workings of medieval reliquaries tends to overlook the textiles that almost always came in most direct contact with the sacred. A careful consideration of the role of textiles in the creation and recreation of the medieval treasury of San Isidoro de León should make us reconsider this approach, asking instead "what do textiles do for relics?"74 As Cynthia Hahn argues,

A reliquary offers more than confinement: it implicates an array of practices such as ritual, storytelling, and collecting ... through a reliquary, its construction and its display of precious materials, it asserts that the relic is by nature valuable, eternal, and has existed from a designated and pregnant historical moment worthy of remembrance ... a reliquary's mission is the support of memory. ${ }^{75}$

Only the most desirable luxury textiles imported from trading centers that connected Europe to Africa and Asia were selected to honor the relics of the saints that rest at the heart of the treasury and mausoleum of San Isidoro. Indeed,

74 Cynthia Hahn, “What Do Reliquaries Do for Relics?" Numen 57 (2010): 284-316.

75 Cynthia Hahn, The Reliquary Effect: Enshrining the Sacred Object (Chicago: University of Chicago Press, 2017), 20. 
luxury silks were among the "gemmis et auro"76 — the objects of highest value-upon which the dazzling performance of the sacred relied. They offered a literal physical veil, and often a series of veils, in the rituals that concealed and revealed, protected and exposed the relics at the moments of activation. ${ }^{77}$ As powerful material capable of temporal and geographic evocation, textiles were fundamental in the process of the visualization of the holy and the mirroring of majesty.

As a result, fine textiles that had undergone ritual consecration and become cult objects had long useful lives and served myriad purposes at León's most emblematic royal foundation, the Basilica of San Isidoro. In direct contact with the remains of Iberian saints of Roman, Visigothic, and Caliphal periods - and throughout a millennium-long process of use, restoration, adaptation, and reuse - the textiles at San Isidoro echoed the notion of antiquity and triumphant Christianity that legitimized royal claims to the Iberian territory. There is much work left to untangle the intricate web of changes and movement of relics and their textile covers - not least a careful archival study of nineteenthand twentieth-century translations within the institution itself and the city of León at large. The evidence is clear, however, that such a dynamic ritual environment made the present-day treasury of San Isidoro a vastly transformed collection of objects that is far more complex than traditionally conceived.

\section{Acknowledgments}

Republication of this study in the present volume was supported by the Index of Medieval Art (Princeton University) and The Medieval Iberian Treasury in Context: Collections, Connections, and Representations on the Peninsula and Beyond (National Research Challenge Grant, Spanish Ministry of Science, Innovation, and Universities, AEI/FEDER, RTI2018-o98615-B-Ioo, 2019-2022, PI Therese Martin).

76 Cynthia Hahn, Strange Beauty: Issues in the Making and Meaning of Reliquaries, 40o-circa 1204 (University Park, PA: The Pennsylvania State University Press, 2012), 26.

77 Hahn, The Reliquary Effect, 13-14; Massimo Leone, "Wrapping Transcendence: The Semiotics of Reliquaries," Signs and Society 2/S1 (2014): S49-S83. 